\title{
Assessing the efficacy of open distance learning in South Africa
}

\author{
Frans Khutso Kgobe \\ Institute of Public Affairs \& Governance, South Africa \\ Mokoko Piet Sebola \\ University of South Africa, South Africa
}

\section{Keywords}

Access, Distance learning, Efficacy, Higher Education, Legislation

\begin{abstract}
The aim of this paper is to explore the effectiveness of open distance learning in South Africa. Most developing countries in the world are facing challenges of expanding access to higher education. These challenges are even more acute in places of limited resources and capacity to provide quality higher education for an ever-increasing population. For many countries in Africa, distance education seems to be the only option to play a role in widening participation to higher education problems. While recognising the necessity of distance education in widening access, it must also provide academically credible and quality education content that is effective and efficient. Given the emergence of Covid-19 most universities in South Africa are moving towards the distance education, which author(s) argue that effectiveness of this model is challenged. This paper is purely conceptual and adopts a desktop methodology and to underpin the argument the paper will further rely heavily on the perusal of the available literature to support the argument carried out. Thus, to realize the aim of this article, the author(s) benefited from Critical Discourse Analysis (CDA) of secondary data covering open distance learning. The article revealed that open distance learning is challenged by covid-19 and that it is not effective. Thus, assessments are done solemnly online which affect the effectiveness of distance education. The article recommends that all provisions and regulations guiding open distance learning needs to be revisited and amended as to make the education more effective even in difficult times.
\end{abstract}

\section{Introduction}

In the course of these years, universities have worked on a range of innovative technologies to provide the most effective service for distance learning students (Makoe, 2011). In addition to the world's needs for mass higher education and a larger array of students, the function of the online mentor is increasingly recognizable in university education (Chang, Shen, \& Liu, 2014). Williams emphasizes the mentor's important role in the development of all types of informational communication (2002). The latest advancements in networking and immersive learning systems have a major impact on the interaction between the student and the business and the learning process. Brown (2002) argues, in order to cover certain e-learning settings in the modern education system, the different activities must be integrated.

E-tutor functions cannot be generalised on the basis of a special sense of e-learning (Metz and Bezuidenhout, 2018). In this study, the University of South Africa is the largest ODL institution in South Africa and the only university specializing in distant education in Southern Africa. The University has good rates for distant education (DE) compared with residential universities within the continent (Mashile, 2012). In this article we argue that due Covid 19 pandemic, the ODL learning model by Open Learning Distance Universities is challenged in similar way as the residential universities. Both are struggling to implement an ODL learning model. The question therefore raised in this article is: How can we improve the ODL learning model during the Covid 19 pandemic? In addressing this question, the paper covers the following aspects, namely the methodological approach, the relevance of digital learning, open distance learning and digital technologies in this context.

\section{Methodological approach}

No research may be conducted without the design of the research. For the execution of any study, research designs are essential. Kumar (2011) considers research designs a process strategy adopted by 
academics to address issues of research. In relation to Pandey and Pandey (2015), these are the frameworks used in the data collection and analysis procedures. Qualitative approaches typically produce rich and thorough data, providing ideas and thoughts to inform your study. MacDonald \& Headlam (2014) suggests that they are able to disclose people's feelings and how they think without giving the target audience the numbers that they are feeling or thinking. This study adopts a qualitative technique for research. Therefore, a qualitative design. Bryman (2020) shows that quality research is a compilation of social data that focuses on meaning and gives useful insights into the study populations' local views. They can contribute to rich cultural and contextual data (Mack, et al. 2005). In the qualitative investigation, the researcher relied around the terminology "cases and contexts" and cultural signification on the concept of interpretative or critical social science (Neuman, 2014). The logic of continuous practice while following a nonlinear research route is supported by a qualitative study (Neuman, 2014). The current literature has been evaluated and summarized carefully. This procedure involves the evaluation of journals, books, public laws, and Internet sources that have been evaluated by peers. The author also used a qualitative research technique to achieve the objectives of this article using secondary data. The paper so use information from published articles, reports, journals, books, and other materials that were publicly available.

\section{Understanding Open Distance learning (ODL)}

The notion of open distance education has consequently evolved to give consolation to busy students who are not part of the regular university structure (Towobola and Raimi, 2011). Makoe, (2015) said that open distance learning is meant for a student who is away from the teacher and who mostly uses media for learning. Open distance learning is further described by the Policy (DHET, 2014:2) as typically "involving making provision to support a wider range of student choices regarding access, curriculum, pacing, sequencing, learning modes and methods, assessments, and articulation" (Prinsloo, 2015:24). Open distance learning (ODL) is a flexible way of learning for individual and group delivery, which is conceptualized in educational literature (Towobola and Raimi, 2011). Open distance learning is provided to students who are not physically present in a specific geographical location and who could not fit into the traditional educational setting involving attending classroom sessions (Towobola and Raimi, 2011) for various reasons which are convenient for the student to choose that path for learning.

Universities' open distance learning is a real mechanism for accessing mass education possibilities for a significant part of the country's population. Towobola and Raimi (2011) therefore believe that open distance study is open for institutions wanting to implement a program of remote learning in line with worldwide best practices. ODL is a method that is meant to offer access to learning when the source of information and learners are separated by time, distance physically and geographically or a mix of both (Honeyman and Miller, 1993). The main goal of ODL institutions is according to Makoe (2015) to expand learning possibilities for individuals who have had no opportunity to study. More often these students are working and do not have time to attend classes on full time basis. Such students are the $\mathrm{n}$ capable of sharing their learning time with some of their commitment such as full-time employment.

\section{The current state of Affairs of the open distance learning in South Africa`s Higher Education}

The higher education system of South Africa has seen significant development, structurally (including important consolidations), and cultural alterations since the end of the apartheid era (Karodia, Shalkh \& Soni, 2015; Ariail, 2015). Makoe (2015) believes that even universities located on campuses increasingly provide or explore open distance learning programmes. The latter occurs with Covid-19 as most higher education institutions have moved from campus education to e-learning. The globalization of higher education in South Africa has had a major influence on distance education (Ariail, 2015). Murphy (2020) indicated that there have been substantial changes in social interaction and organisation. The spread of COVID-19 coronavirus affected and brought about challenges in the higher education sector like it did in other education sectors. The world is full of unpredictability and therefore the South African institutions for higher learning (HEIs) were not spared from unanticipated events (Mashau and Nyawo, 2021).

Mashilo and Selelo (2021), opines that discourse, as opposed to merely the necessity to change towards a new age of education, applied to the impact of the COVID 19 epidemic on the quality of 
education in higher learning institutions in South Africa. In Dhawan's report (2020) the epidemic has highlighted the inadequacies of the university system in order to adapt digital technology instructors to the rapidly changing environment of education around the world (Dhawan, 2020). Rashid \& Yadav (2020) argued that higher education institutions throughout the world were intense and popular in responding to an emergency pandemic, which reveals a rapid shift to the online learning system. In the meanwhile, Mashilo and Selelo (2021), are of the view that the pandemic exposed the flaws, inadequacies and value of digital culture in poor countries and rising countries during the pandemic period.

Not every student and lecturer have regular or secure Internet access. In many cases, internet connection may be limited to dial-up speed, or its internet may have a covered monthly usage that might reduce their ability to access or draw data. Sometimes, due of large families and commotion in the house, students are less comfortable to learn in the home environment (Jena, 2020). Furthermore, given a unique setting in which the students live, the problem of networking to online learning is a different experience for some (Toquero, 2020a). Distance students often feel alienated and lack confidence in studying. This is especially true for kids who encountered an online forum (Metz and Bezuidenhout, 2018). In supporting and giving students such a platform, e-tutors will be an important part of the support system.

\section{Open Distance Learning And E-Learning}

The reality that digital technology facilitates open-distance learning at institutions cannot be avoided. Without recognizing the importance of digital technology in this process, nobody can talk about open distance learning. Distance learning also involves a combination of technological and digital factors (Azorin, 2020). South African higher education institutions are somewhat equipped for this digital migration without being beyond the scope of the task. This is because certain privileged universities have finished their academic year effectively employing technological instruments and applications (Dawadi, Giri \& Simkhanda, 2020). These include the universities of Pretoria, Cape Town, Johannesburg University and Wits University. Despite the problems encountered by higher education institutions, particularly disadvantaged universities, multimodal learning is practicable, since these universities have invested and increased their ICT infrastructure capacity and labour force (Daniel, 2020).

\section{The Benefits of Open Distance Learning}

It should be noted that the digital network enables learning from an open distance. Open-distance and digital/online learning are therefore synonymously utilized for this paper and are so employed to avoid misunderstanding. Therefore, both students and universities worldwide gain from online training. Since the breakout of COVID-19 the development of Online Learning has attracted attention. As such, at the universities and colleges such as in South Africa online learning and teaching has been extensively supported with enormous resources.

Online learning and education may be more beneficial and useful for students and facilitators repeatedly. Students can operate inside the structure themselves and the interaction of on-line learning and training may be divided into more modest, unstoppable bits of time with an opportunity to show up in the middle (Jena, 2020). Another advantage of online learning is that it enables students to study from any field of choice (Jacob, Abigeal \& Lydia, 2020). It also allows universities not to be restricted to geographical limitations but to connect to a wider network of students. In addition, for future references, online discussions may be registered, documented, and shared (Jena, 2020). This allows pupils to access the instructional material at a time of consolation. Internet learning therefore provides students with time and place available for instruction. However, digital content-based knowledge acquisition produces computerized expertise, which is becoming necessary in modern society and working situations (Daniel, 2020).

Every student has a varied taste for studying in different styles. Some students are visual students, while some students want to study auditory. In addition, a few students bloom in the home, and other sub-studies are individual students who are distracted by big meetings (Gautam 2020). The online learning system may be personalized from several points of view with its range of options and assets (Toquero, 2021). It is the perfect way to create an optimal learning environment suited to each student's needs. 
The online learning approach is best suited for everybody. This sophisticated transformation led to stunning improvements in access, testing and sharing of material (Jacob, Abigeal and Lydia, 2020). Office participants and housewives can take online instruction courses when appropriate (Jena, 2020). Depending on their accessibility and consolation, during weekend or at night many people prefer to learn. It guarantees access and fair opportunity for all, so that online transmissions provide students and facilitators with disabilities the chance or have difficulties in their availability that confines themselves to an eye-to-eye lesson (Daniel,2020).

Gupta, (2017) highlights the effectiveness of open distance learning that it:

makes it simple to get a handle on the content and review it

It brings about improved scores on certifications, tests, or different kinds of assessment.

Higher number of students who accomplish pass or dominance level.

Improved capacity to learn and carry out the new cycles or information at the working environment.

Help in holding information for a long period

It can be deduced from the above that e-learning is the most effective form of educational instruction, especially considering the challenging COVID 19 facing the globe today. Indeed, when the pandemic ends, the academic fraternity would have learned a bit about e-learning opportunities in the educational environment.

\section{Efforts Made by the Government and Institutions of Higher Learning During the Covid 19 Pandemic}

This paper uses South Africa as a case of reference to examine the viability of open distance learning in the institutions. "A point worth mentioning is that higher education as a sector has embraced ICTs, which are seen not only as an impetus of change in traditional concepts of teaching and learning, but also as prime motivations behind the higher education change as the interplay of technological developments and socio-economic change, shape the processes of teaching and learning" (Mbatha and Naidoo, 2010: 65). Like in other countries, including Spain, Italy, China and Kenya, certain higher education institutions continue to experience migration to open-distance learning problems. The problem is to implement weak ICT infrastructure for open-distance study. The institutions did not absolutely or entirely fail to provide open distance learning because the university and the government tried to do open distance learning (Toquero, 2020).

The similar practise is used in South Africa by distributing computers and databases to students to access online learning through governments and institutions. The institutions have also been enhanced and invested in their online learning ICT infrastructure (Reimers \& Schleicher, 2020). One conclusion is that online learning is feasible at institutions with few obstacles. "Unisa's open learning policy promotes open access to courses, flexibility in learning provision, flexibility in methods and criteria of assessing learning process and achievement, and lifelong learning as propagated by the Commonwealth of Learning" (Sonnekus, Louw, and Wilson, 2006; Mbatha, and Naidoo, 2010:64).

\section{Conclusion}

The interpretation of open distance learning shows the necessity for research in the future to assess how qualified students can participate in the online management system and contribute to low levels of engagement of e-tutors. In recognizing the importance of these tasks and the identification of the required teaching abilities, the performance of e-learning techniques is crucial. In general, ICT's may be substantially helped by the opportunities of remote education in instances when there are large numbers of non-approached instructors, inadequate service preparedness and few training centers or trainers.

\section{References}

Ariail, D. L.(2016). Globalization of Higher Education in South Africa. Georgia Journal of College Student Affairs, 32(1). https://doi.org/10.20429/gcpa.2016.010107

Azorín, C. (2020). Beyond COVID-19 supernova. Is another education coming? Journal of Professional Capital and Community, 5(3): 381-390.

Brown, C. (2002). Simple and effective - Teacher roles remain a powerful framework to embed ICT within the practice of teaching. In D. Willis, J. Price, \& N. Davis (Eds), Proceedings of SITE 2002 -Society for Information Technology and Teacher Education International Conference, Nashville, TN.

Bryman, A. (2012). Social research methods. Oxford: Oxford University Press. 
Chang, C., Shen, H., \& Liu, E. Z.(2014). University faculties' perspectives on the roles of e-instructors and their online instruction practice. International Review of Research in Open and Distance Learning,

Daniel, J.( 2020). Education and the COVID-19 pandemic. Prospects, 49(1): 91-96.

Dawadi, S., Giri, R. and Simkhada, P.(2020). Impact of COVID-19 on the Education Sector in Nepal-Challenges and Coping Strategies. Sage Submissions. Preprint.

Department of Higher Education and Training. (2014). Policy for the provision of distance education in South African universities in the context of an integrated post-school system. Retrieved from

gov.za/documents / download.php?f=213796

Dhawan, S. (2020). Online learning: A panacea in the time of COVID-19 crisis. Journal of Educational Technology Systems, 49(1), 5-22

Gautam, P.(2020). Advantages And Disadvantages of Online Learning. https://elearningindustry.com/advantagesand-disadvantages-online-learning

Gupta, S. (2017). 9 Benefits Of eLearning For Students.

Honeyman, M. and Miller, G. (1993). Agriculture distance education: A valid alternative for higher education?". Proceedings of the 20th Annual National Agricultural Education Research Meeting: 67-73

Jacob, O.N., Abigeal, I. and Lydia, A.E.(2020). Impact of COVID-19 on the higher institution's development in Nigeria. Electronic Research Journal of Social Sciences and Humanities, 2(2):126-135.

Jena, P.K.( 2020). Impact of pandemic COVID-19 on education in India. International Journal of Current Research (IJCR), 12.

Karodia, A. M., Shaikh, A., \& Soni, D. (2015). The South African universities post-merger mess:

Kumar, R. (2011). Research methodology: A step-by-step guide for beginners. London: Sage Publications Limited.

MacDonald, S., \& Headlam, N. (2014). Research methods handbook: Introductory guide to research methods for social research. United Kingdom: Centre for Local Economic Strategies.

Mack, N., Woodsong, C., Macqueen, K.M., Guest, G.N., \& Namey, E. (2005). Qualitative Research Methods: A Data Collector's Field Guide. Family Health International.

Makoe, M. (2011). Academics going mobile: new roles for new technologies. Progressio, 33(2), 174-188.

Makoe. M.(2015). A fit for Purpose Mission for Widening Access through Open distance learning. (Eds). In Letseka, M., Education in A Competitive and Globalzing World. Nova Publishers. New York

Mashau, P. and Nyawo, J.C.(2021). The use of an online learning platform: a step towards e-learning. South African Journal of Higher Education, 35(2), pp.123-143.

Mashile, O. (2012). Unisa tutor model. Report compiled for Senate Teaching and Learning Committee, March 2012. Pretoria: University of South Africa.

Mashilo M.T., \& Selelo, M.E. (2021). The impact of covid-19 on the quality of education in institution of higher learning: an exploratory study in the University of Limpopo International Journal of Entrepreneurship, 25(4): 01-10.

Mbatha, B., and Naidoo, L.(2010). Bridging the transactional gap in Open distance Learning (ODL); The case of the University of South Africa (Unisa). Inkanyiso Journal of human and Social Science. 2(1):64-69

Metz, N., and Bezuidenhout, A.(2018). An importance-competence analysis of the roles and competencies of e-tutors at an open distance learning institution. Australasian Journal of Educational Technology, 34(5): 27-43

Michael, P A.M (2020). COVID-19 and emergency eLearning: Consequences of the securitization of higher education for post-pandemic pedagogy. Contemporary Security Policy

Neuman, W.L. (2014). Social research methods: Qualitative and Quantitative Approaches (7th ed.). Hallo: Pearson Education Limited Harlow

Pandey, P., \& Pandey, M.(2015). Research methodology: Tools and techniques. Buzau: Bridge Center.

Prinsloo, P.(2015). Participation in Open distance Learning. (Eds). In Letseka, M., Education in A Competitive and Globalzing World. Nova Publishers. New York. Pp 21-37

Rashid, S., \& Yadav, S.S. (2020). Impact of Covid-19 pandemic on higher education and research. Indian Journal of Human Development, 14(2): 340-343.

Reimers, F.M. and Schleicher, A.(2020). A framework to guide an education response to the COVID-19 Pandemic of 2020. OECD.

Toquero, C.M. (2020a). Challenges and Opportunities for Higher Education Amid the COVID-19 Pandemic: The Philippine Context. Pedagogical Research, 5(4).

Toquero, C.M.( 2020b). Emergency remote teaching amid COVID-19: The turning point. Asian Journal of Distance Education, 15(1):185-188.

Toquero, C.M.( 2021). Emergency remote education experiment amid COVID-19 pandemic. IJERI: International Journal of Educational Research and Innovation, (15): 162-176.

Towobola, W. L and Raimi, L. (2011). Open distance learning (ODL): A catalyst for educational and entrepreneurship development in Nigeria. Continental Journal of Education Research 4 (3): 1 - 11. 